\title{
Teaching Indefinite Articles in English Using Hindi Speech Sounds: A
}

\section{Classroom Action Research}

\section{Disha Esther Ramtek}

Assistant Professor

St. Aloysius Institute of Technology

Madhya Pradesh, India

disharamtek25@gmail.com

Abstract

This paper focuses on teaching the use of indefinite articles ' $a$ ' and 'an' appropriately to the students who have had their schooling from Hindi medium schools and are presently pursuing bachelor and diploma courses. It was seen that these students fail to use correct indefinite articles before English words because of the lack of knowledge of consonant and vowel sounds in English language, further to solve this issue a technique was introduced to the students where they could use their prior knowledge of sounds associated to Hindi letters of alphabet. Classroom action research was performed for the fulfillment of the purpose of this research.

Keywords: Articles, Indefinite Articles, Consonants, Vowels, Hindi Medium Schooling, English Language, Hindi Language, Speech Sounds Introduction

Articles play a very important role in ensuring that we speak and write correct English. A wrong use of articles can sometimes lead to a change in the meaning of the word altogether. Use of some articles depends strictly on the sound produced by them (Dhillon et al. 66).While teaching 'articles' to college students who have completed their schooling from Hindi medium schools, have Hindi as their mother tongue and had less or no proper English 
training and education before, it was noticed that they lack the knowledge of phonetics or even basic information of consonant and vowel sounds. Some of them only relate to the letters of the English alphabet that represent the vowel and consonant sounds. When asked, what are vowels? These students simply say, "a, e, i, o, u”. While some others have absolutely no idea of the concept of consonants and vowels.

The lack of knowledge of the concept of speech sounds makes it difficult for them to use correct indefinite articles before English words. The students generally see the first letter of the word and if they find the letters a, e, i, o or $\mathrm{u}$ at the beginning of the word they use article 'an' even if the letters are not representing a vowel sound. Similarly, they fail to use article 'an' before the words that begin with a consonant letter but produce a vowel sound. Hence the aim of this research was to introduce a technique where students can use their prior knowledge of sounds of the letters of Hindi alphabet to figure out if an English word must proceed with either article 'a' or 'an' and evaluate if this technique proves to be successful. Articles:

Articles are words that define a noun as specific or unspecific. English has two types of articles: definite and indefinite. 'The' is used to refer to particular or specific nouns, such as something unique, something previously mentioned or known, something being identified by the speaker. While 'a' and 'an' are used to refer to non-particular or unspecific nouns, such as, something mentioned for the first time, something generic.

Article 'the' can be used before both singular and plural nouns, while article 'a' and 'an' are used only before singular nouns. 'A' precedes a word that begins with a consonant sound and 'an' precedes a word that begins with a vowel sound.

Sometimes, an article modifies a noun that is also modified by an adjective. The word order then becomes 'article + adjective + noun'. In such cases if indefinite article is to be used, then 'a' or 'an' are used on the basis of the word that immediately follows it. Articles 
are classified as determiners. A determiner is used before a noun to indicate possession, quantity, definiteness or specificity.

Consonants and Vowels:

Consonants and vowels are two categories of speech sounds. Phonetics is a branch of Linguistics, which deals with production of speech sounds. Thus, the study of speech sound is known as Phonetics (Sarangi 141). A vowel is a speech sound that is produced with the mouth open, which allows air from the lungs to flow without any significant constriction. The tongue can be at various heights i.e., high, mid or low, within the mouth and at various positions; front, central or back. The lips can be rounded or unrounded to create the correct sound. While a consonant is a speech sound produced by partial or complete blocking of the flow of air using the palate, tongue, teeth and lips.

Every language has vowels and consonants but their numbers may vary. The English language is created through different combinations of 44 sounds out of which 20 are vowels and the rest 24 are consonants. In written language the letters of the alphabet are referred either as vowels or consonants depending on the type of sound they are representing. Written English has 26-letter alphabet. Of these 26 letters, 20 are proper consonants and five are proper vowels. One, the letter $y$, can be considered either a consonant or vowel depending on usage. The proper vowels are a, e, i, o, and u(Nordquist) (Figure 1).Standard Hindi has 11 vowels and 35 consonants but in traditional Hindi there are 13 vowels and 33 consonants.(Figure 2) In Hindi consonants and vowels are similar in number in spoken and written language.

\begin{tabular}{|c|c|c|c|c|}
\hline \multicolumn{5}{|c|}{ Consonants } \\
\hline $\mathrm{b}$ & $\mathrm{c}$ & $\mathrm{d}$ & $\mathrm{f}$ & $\mathrm{g}$ \\
\hline $\mathrm{h}$ & $\mathrm{j}$ & $\mathrm{k}$ & $\mathrm{l}$ & $\mathrm{m}$ \\
\hline $\mathrm{n}$ & $\mathrm{p}$ & $\mathrm{q}$ & $\mathrm{r}$ & $\mathrm{s}$ \\
\hline
\end{tabular}




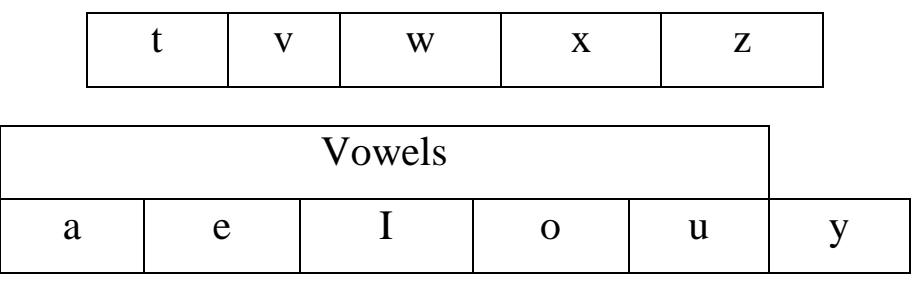

Figure1

\begin{tabular}{|c|c|c|c|c|c|}
\hline \multicolumn{6}{|c|}{ Vowels (स्वर) } \\
\hline अ & आ & इ & ई & उ & ऊ \\
\hline ॠ & ए & ऐ & ओ & औ & अं \\
\hline अ: & \multicolumn{6}{|l|}{} \\
\cline { 2 - 5 } &
\end{tabular}

\begin{tabular}{|c|c|c|c|c|}
\hline \multicolumn{5}{|c|}{ Consonants (व्यंजन) } \\
\hline क & ख & ग & घ & ङ \\
\hline च & छ & ज & झ & ज \\
\hline ट & ठ & ड & ढ & ण \\
\hline त & थ & द & ध & न \\
\hline प & फ & ब & भ & म \\
\hline य & र & ल & व & श \\
\hline ष & स & ह & & \\
\hline
\end{tabular}

Figure 2

\section{Research Context}

The problem of lack of knowledge of consonant and vowel sounds in English language was noticed among the students of two different classes. The first class was of first year bachelor students of St. Aloysius Institute of Technology, Madhya Pradesh, India, having 46 students who were 18 to 20 years of age. The second class was of first year diploma students of Kalaniketan Polytechnic College, Madhya Pradesh, India, having 39 students who were 20 to 30 years of age. Though the age of the participants and the courses they were pursuing were different, the commonality was that they all had their schooling from Hindi medium schools. 
Students were given a set of 10 fill in the blank questions on articles where they had to use appropriate indefinite articles to fill up the blacks (Set 1). The 10 questions can be considered under two categories. The first category of questions $(2,3,4,6,8$ and 9$)$ had words succeeding blanks that begin with vowel letters representing vowel sounds and consonant letters representing consonant sounds. While the second category of questions $(1,5,7$, and 10) had words succeeding blanks that begin with either vowel letters giving effect of consonant sounds or consonant letters producing effect of vowel sounds. The list of questions was as follows (Set 1):

1. This phone has unique feature.

2. I met boy in the store.

3. She was wearing ugly dress when she met him.

4. Mallorca is island.

5. Please give me one-rupee coin.

6. Sara has new boyfriend.

7. She lives in Europe. She is European.

8. Can you write letter?

9. You must eat apple every day.

10. Sheena is surely honest girl.

\section{Bachelor Students Answering Pattern}

(Set 1)

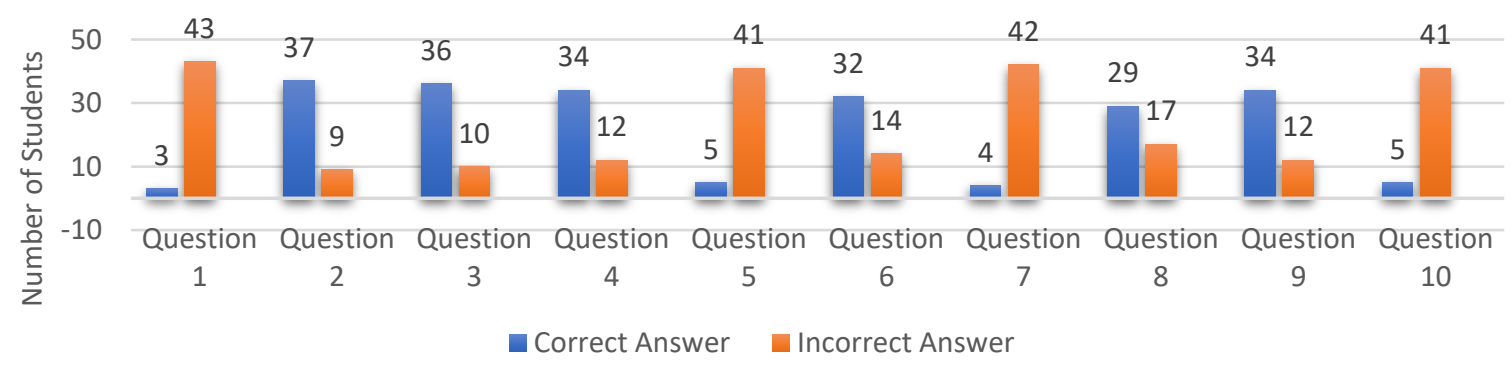

Chart 1 


\section{Diploma Students Answering Pattern}

\section{(Set 1)}

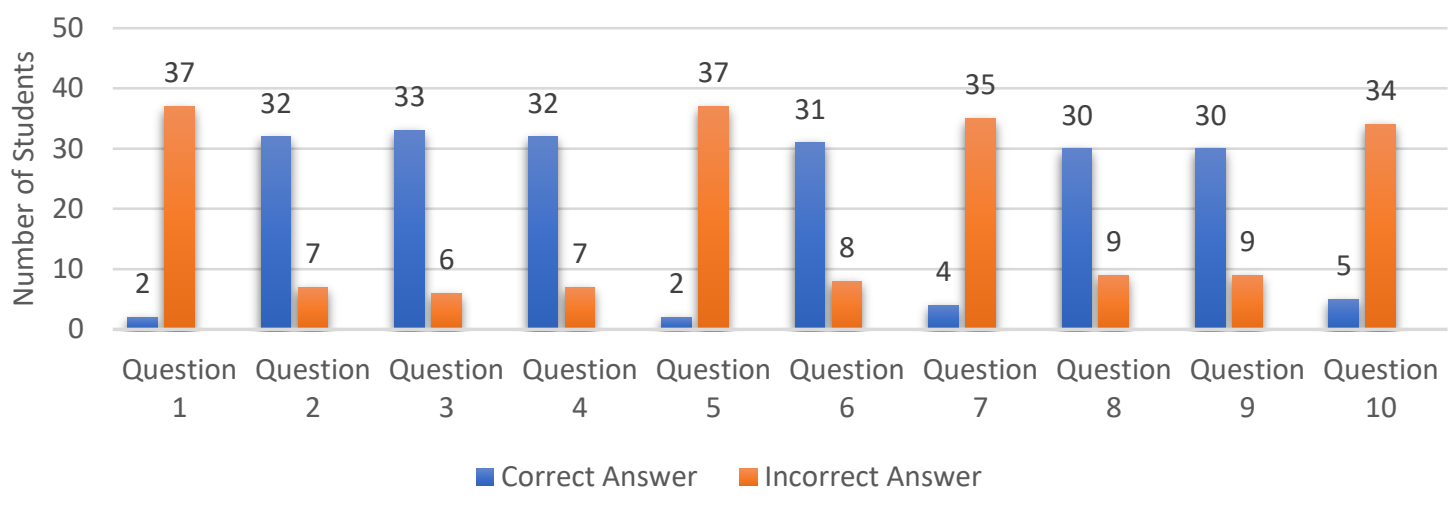

Chart 2

While answering specifically the second category of questions i.e., 1, 5, 7 and 10 similar answering patterns were noticed among both the groups. Chart 1 shows the answer pattern of bachelor students and Chart 2 shows the answer pattern of diploma students. From both the charts it is clear that most of the students got confused between the letters of English alphabet and the way they are pronounced in the word, hence, they failed to use appropriate indefinite articles. The correct answers were as follows:

1. This phone has a unique feature.

2. I met a boy in the store.

3. She was wearing an ugly dress when she met him.

4. Mallorca is an island.

5. Please give me a one-rupee coin.

6. Sara has a new boyfriend.

7. She lives in Europe. She is a European.

8. Can you write a letter?

9. You must eat an apple every day.

10. Sheena is surely an honest girl.

Research Methodology 
Classroom Action Research was used to find out if the technique of using prior knowledge of sounds of Hindi letters of alphabet to find out if the English words are truly beginning with consonant or vowel sound and further using appropriate indefinite article where needed. An empirical study was carried out by the means of direct observation on the students of both the classes.

By the time the action research was to be commenced the students knew what are articles and their usage. They understood that written English has 5 vowel letters a, e, i, o and u. Following steps were followed to make the students understand how to imply their knowledge of sounds of Hindi letters:

Step 1: Taking up a fill in the blank type question in which correct indefinite article is to be used before succeeding word.

Sudha is going to receive award.

Step 2: Notice the word after the blank and pronounce it loudly.

Sudha is going to receive award.

Step 3: The word 'award' begins with a sound similar to the Hindi letter 'अ'. 'अ' comes under Hindi vowels(स्वर माला).

Step 4: Since it is now clear that the word 'award' begins with a vowel sound the students can write article 'an' to fill in the blank.

Sudha is going to receive an award.

The above steps were repeated a few times with various examples to help the students understand the technique clearly. The students were made clear that this technique is for their ease and that the system of consonants and vowels of English and Hindi are much more elaborate and are not completely similar to each other. 
To test if the above explained technique is helping the students to use indefinite articles 'a' and 'an' correctly, another set of 10 questions was given to the two classes (Set 2). Following were the fill in the blank questions:

1. It is lovely day.

2. It is auspicious occasion for my family.

3. Jane's grandfather is honorable man.

4. I saw yellow car.

5. The speed of this car is 150 miles hour.

6. You will have to go to the hospital for X-ray.

7. My brother is school teacher and my sister is architect.

8. Please call the doctor, its emergency.

9. Pollution has become universal problem.

10. Michael is unusual man.

In the above set of questions, question $1,2,4,7,8$ and 10 come under the earlier mentioned first category of questions and question 3, 5, 6, and 9 come under the second category of questions.

Result and Discussion

Students of both the classes enthusiastically applied the technique of using prior knowledge of Hindi vowels (स्वर)and consonants(व्यंजन)to use appropriate indefinite articles before English words. They carefully read the given questions one-by-one, loudly pronouncing English words succeeding the blanks to find out what sound is being produced by the first letter of the given English word and trying to connect to the letter of Hindi alphabet that produces similar sound. Further checking if that Hindi letter comes under vowel (स्वर)or consonant (व्यंजन)category, therefore using indefinite article ' $a$ ' before consonant and indefinite article 'an' before vowel. 
A great improvement was recorded in the answering pattern of the students. The bachelor students showed an improvement of $10 \%$ to $15 \%$ while answering questions falling in the first category and there was an appreciable $60 \%$ to $80 \%$ improvement in answering pattern of questions falling in the second category. Chart 3 shows the overall answering pattern of bachelor students. The diploma students showed an improvement of $10 \%$ to $15 \%$ while answering questions falling in the first category and there was amassive $70 \%$ to $90 \%$ improvement in answering pattern of questions falling in the second category. Chart 4 shows the overall answering pattern of diploma students.

\section{Bachelor Students Answering Pattern}

\section{(Set 2)}

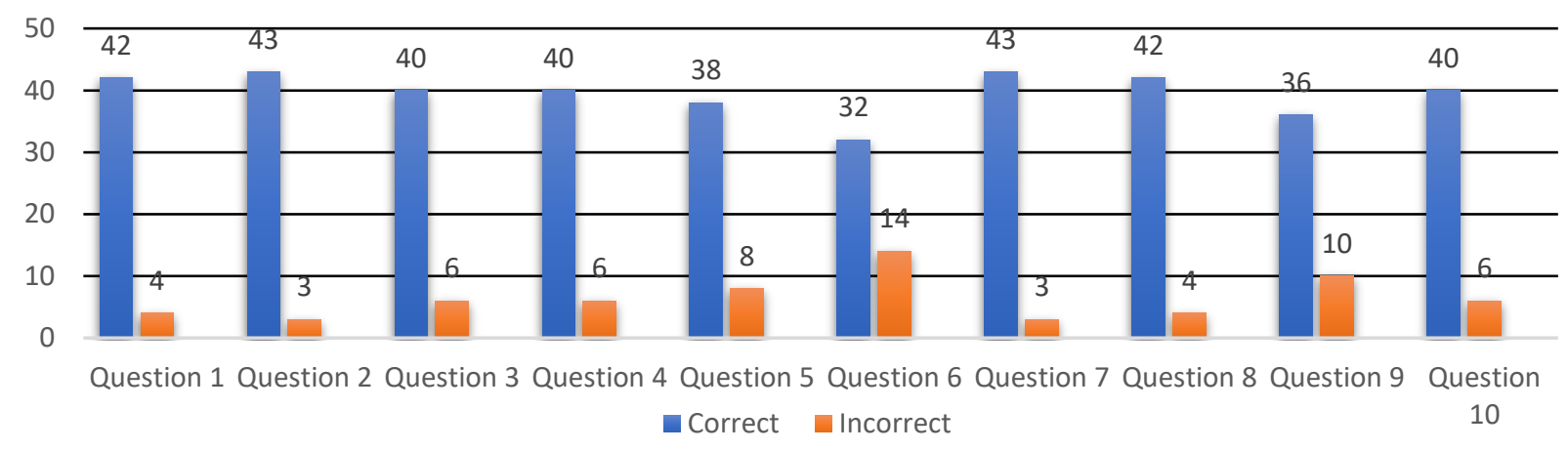

Chart 3 


\section{Diploma Students Answering Pattern}

(Set 2)

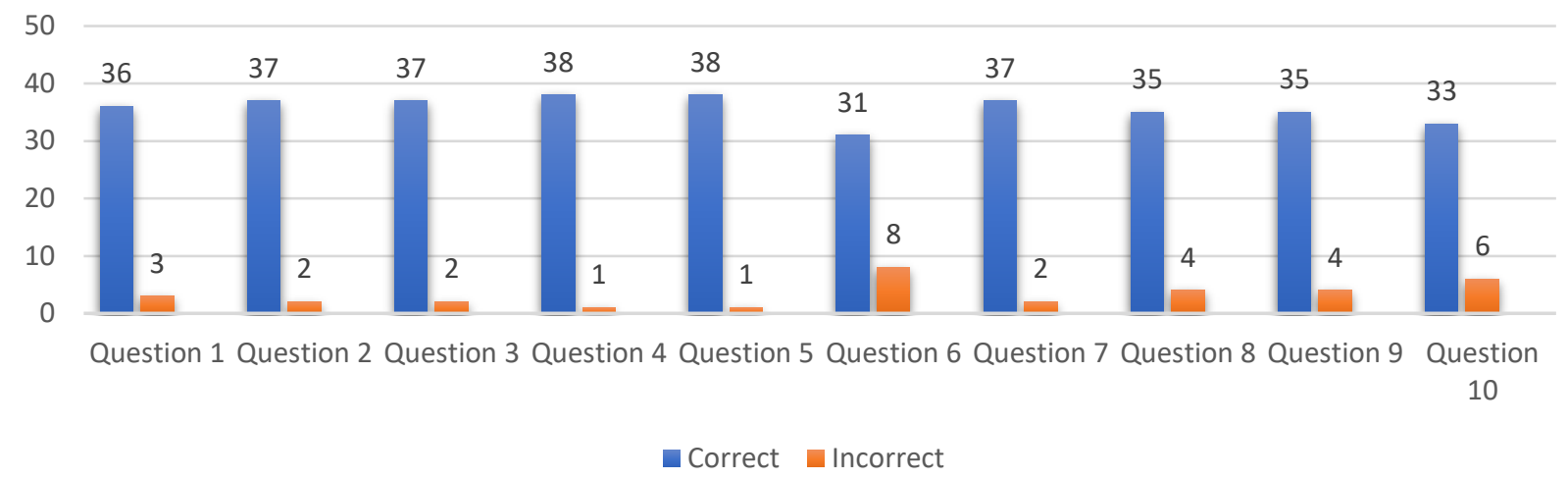

Chart 4

The improvement in the students regarding the use of correct indefinite articles before English words by using the suggested technique can be clearly notedlooking at theabovementioned results. The following table (Table 1)shows how this technique works:

\begin{tabular}{|c|c|c|c|c|c|c|c|}
\hline $\begin{array}{l}\text { Q. } \\
\text { No }\end{array}$ & Question & $\begin{array}{l}\text { Word } \\
\text { Succeeding } \\
\text { the blank }\end{array}$ & $\begin{array}{c}\text { English } \\
\text { Pronunciation } \\
\text { of the Word }\end{array}$ & $\begin{array}{c}\text { Similar } \\
\text { Sounding } \\
\text { Hindi } \\
\text { letter } \\
\text { (Only the } \\
\text { first } \\
\text { letter) }\end{array}$ & $\begin{array}{l}\text { Whether } \\
\text { the Hindi } \\
\text { Letter is a } \\
\text { Consonant } \\
\text { or vowel }\end{array}$ & $\begin{array}{l}\text { Appropriate } \\
\text { Article to be } \\
\text { used } \\
\text { Depending } \\
\text { on } \\
\text { Consonant } \\
\text { and Vowel }\end{array}$ & $\begin{array}{l}\text { Final } \\
\text { Answer }\end{array}$ \\
\hline 1. & $\begin{array}{l}\text { It is } \\
\text { lovely day. }\end{array}$ & lovely & luhv'lee & ल & Consonant & $\mathrm{a}$ & $\begin{array}{l}\text { It is a } \\
\text { lovely day. }\end{array}$ \\
\hline 2. & $\begin{array}{l}\text { It is } \\
\text { auspicious } \\
\text { occasion } \\
\text { for my } \\
\text { family. }\end{array}$ & auspicious & aw.spish.uhs & औ & Vowel & an & $\begin{array}{l}\text { It is an } \\
\text { auspicious } \\
\text { occasion } \\
\text { for my } \\
\text { family }\end{array}$ \\
\hline 3. & Jane's & & $\mathrm{aw} \cdot \mathrm{nuh} \cdot \mathrm{rei} \cdot \mathrm{bl}$ & ऑ & Vowel & an & Jane's \\
\hline
\end{tabular}




\begin{tabular}{|c|c|c|c|c|c|c|c|}
\hline & $\begin{array}{l}\text { grandfather } \\
\text { is } \\
\text { honorable } \\
\text { man. }\end{array}$ & honorable & & & & & $\begin{array}{l}\text { grandfather } \\
\text { is an } \\
\text { honorable } \\
\text { man. }\end{array}$ \\
\hline 4. & $\begin{array}{l}\text { I saw } \\
\text { yellow car. }\end{array}$ & yellow & yeh.loh & य & Consonant & $\mathrm{a}$ & $\begin{array}{l}\text { I saw a } \\
\text { yellow car. }\end{array}$ \\
\hline 5. & $\begin{array}{l}\text { The speed } \\
\text { of this car } \\
\text { is } 150 \\
\text { miles _- } \\
\text { hour. }\end{array}$ & hour & $a w \cdot u h$ & आ & Vowel & an & $\begin{array}{l}\text { The speed } \\
\text { of this car } \\
\text { is } 150 \\
\text { miles an } \\
\text { hour. }\end{array}$ \\
\hline 6. & $\begin{array}{l}\text { You will } \\
\text { have to go } \\
\text { to the } \\
\text { hospital for } \\
\text { X- X- } \\
\text { ray. }\end{array}$ & X-ray & eks-rey & $\breve{\text { ए }}$ & Vowel & an & $\begin{array}{l}\text { You will } \\
\text { have to go } \\
\text { to the } \\
\text { hospital for } \\
\text { an X-ray. }\end{array}$ \\
\hline 7. & $\begin{array}{l}\text { My brother } \\
\text { is } \\
\text { school } \\
\text { teacher and } \\
\text { my sister is } \\
\text { architect. }\end{array}$ & $\begin{array}{l}\text { school, } \\
\text { architect }\end{array}$ & $\begin{array}{l}\text { skool, } \\
\text { aa·kuh·tekt }\end{array}$ & स, आ & $\begin{array}{l}\text { Consonant } \\
\text {, Vowel }\end{array}$ & a, an & $\begin{array}{l}\text { My brother } \\
\text { is a school } \\
\text { teacher and } \\
\text { my sister is } \\
\text { an } \\
\text { architect. }\end{array}$ \\
\hline 8. & $\begin{array}{l}\text { Please call } \\
\text { the doctor, } \\
\text { it's_ } \\
\text { emergency. }\end{array}$ & emergency & $\begin{array}{l}\mathrm{i} \cdot \mathrm{muh} \cdot \mathrm{juhn} \cdot \mathrm{se} \\
\mathrm{e}\end{array}$ & इ & Vowel & an & $\begin{array}{l}\text { Please call } \\
\text { the doctor, } \\
\text { it's an } \\
\text { emergency. }\end{array}$ \\
\hline
\end{tabular}




\begin{tabular}{|c|c|c|c|c|c|c|c|}
\hline 9. & $\begin{array}{l}\text { Pollution } \\
\text { has become } \\
\text { universal } \\
\text { problem. }\end{array}$ & universal & $\begin{array}{l}\text { yoo } \cdot \text { nuh } \cdot \text { vuhs } \\
\cdot \text { uhl }\end{array}$ & य & Consonant & $\mathrm{a}$ & $\begin{array}{l}\text { Pollution } \\
\text { has become } \\
\text { a universal } \\
\text { problem. }\end{array}$ \\
\hline 10. & $\begin{array}{l}\text { Michael is } \\
\text { unusual } \\
\text { man. }\end{array}$ & unusual & $\begin{array}{l}\text { uhn } \cdot \text { yoo } \cdot \text { zhoo } \\
\cdot \text { uhl }\end{array}$ & अ & Vowel & an & $\begin{array}{l}\text { Michael is } \\
\text { an unusual } \\
\text { man. }\end{array}$ \\
\hline
\end{tabular}

Table 1

This technique is based on the phonetic similarity of English and Hindi languages, where the students try to draw a connection between the perception of the first letter of any English word and Hindi letter that represents similar sound (see Appendix A \& Appendix B for further understanding).

\section{Conclusion}

This research focused on helping students who had Hindi medium schooling and faced difficulty in using appropriate indefinite articles as they lacked knowledge of consonant and vowel sounds in English language. For this purpose, a Classroom Action Research was conducted, which proved to be successful with the students accurately using indefinite articles 'a' and 'an' where required before English words by using the technique of applying their past knowledge of Hindi vowels (स्वर) and consonants (व्यंजन). 
Appendices

Appendix A

Hindi Pronunciation

\begin{tabular}{|c|c|c|}
\hline \multicolumn{3}{|r|}{ Vowels } \\
\hline $\begin{array}{c}\text { Devanagari } \\
\text { letter }\end{array}$ & IPA & $\begin{array}{c}\text { Example } \\
\text { words }\end{array}$ \\
\hline अ & $/ \Lambda, \partial, \underset{x}{\mathrm{p}} /$ & अणु (aṇu) ə.nu: (atom) \\
\hline आ & $/ a:, a: /$ & आलू $(\bar{a} l \bar{u})$ a:lu: potato \\
\hline इ & $/ \mathrm{I}, \mathrm{i} /$ & इतिहास (itihās) I.tı.ha:s (history) \\
\hline ई & /i:/ & मिठाई (miṭhāī) mi.tha:.i: (sweets) \\
\hline उ & $/ \mho, \mathrm{u} /$ & उर्दू (urdū) vrdu: (urdu) \\
\hline ऊ & /u:/ & ऊन (ūn) u:n (wool) \\
\hline ऋ(ŕ) & $/ \mathrm{l}^{\mathrm{j}}, \mathrm{r} /$ & ऋतु (rtu) $\mathrm{f}^{\mathrm{j}}$ :(i).tu (season) \\
\hline ए & /e/ & एक (ek) e:k (one) \\
\hline ऐ & $/ \varepsilon:, æ:, a: i, \widehat{\varepsilon i} /$ & ऐनक (ainak) ع:nək (glasses) \\
\hline$\breve{ }$ & $/ \varepsilon /$ & ऍक्स किरण (ěkskiraṇ) عkski.rən (X-ray) \\
\hline ओ & /o:/ & ओकाई (okāī) o:.ka:.i: (nausea) \\
\hline औ & $/ 0:, \widehat{\mathrm{ou}} /$ & औरत (aurat) ग:rət (woman) \\
\hline ऑ & $/ \mathrm{p} /$ & ऑस्ट्रेलिया (ŏsțreliyā) ps.tre.lı.ja: (Australia) \\
\hline
\end{tabular}




\begin{tabular}{|c|c|c|}
\hline \multicolumn{3}{|c|}{ Consonants } \\
\hline $\begin{array}{c}\text { Devanagari } \\
\text { letter }\end{array}$ & IPA & $\begin{array}{c}\text { Example } \\
\text { words }\end{array}$ \\
\hline क & $/ \mathrm{k} /$ & रोका (rokā) ro:.ka: (stop) \\
\hline ख & $/ \mathrm{k}^{\mathrm{h}} /$ & खजूर (khajūr) k'ədzu:r (date) \\
\hline ग & /g/ & गाँव (gâ̄v) gẫ::v (village) \\
\hline घ & $/ \mathrm{g}^{\mathrm{h} /}$ & घर (ghar) ghor (house) \\
\hline च & $/ \mathrm{t} \int, \widehat{\mathrm{t} f}, \widehat{\mathrm{ccc} /}$ & चाय (cāy) t ta:j (tea) \\
\hline छ & $/ \mathrm{t} \mathrm{f}^{\mathrm{h}}, \widehat{\mathrm{t} \mathrm{f}^{\mathrm{h}}}, \widehat{\mathrm{cc}} \mathrm{c}^{\mathrm{h}} /$ & अच्छा (acchā) ət $\int . t \int^{h} \mathrm{a}:($ good $)$ \\
\hline ज & $/ \mathrm{d}_{3}, \widehat{\mathrm{d}} 3, \widehat{\mathrm{Jj}} /$ & जाना (jānā) dza:.na: (to go) \\
\hline झ & $/ \mathrm{d}^{\mathrm{h}}, \widehat{\mathrm{d} 3^{\mathrm{h}}}, \widetilde{\mathrm{Jd}^{\mathrm{h}}} /$ & मुझ (mujh) mudz ${ }^{\mathrm{h}}$ (me) \\
\hline ट & $/ t /$ & टापू (țāpū) ta:pu: (island) \\
\hline ठ & $/ \mathrm{t}^{\mathrm{h}} /$ & ठीक (țhīk) thi:k (fine) \\
\hline ड & $/ \mathrm{d}, \mathrm{d} /$ & डर (ḍar) dər (fear) \\
\hline ढ & $/ \mathrm{d}^{\mathrm{h}} /$ & ढेर (ḍher) d die:r (heap) \\
\hline ण & $/ \eta, \tilde{\mathfrak{r}}, \breve{\mathrm{n}} /$ & अणु (aṇu) anu: (atom) \\
\hline त & $/ t, \mathrm{t} /$ & अंत (ant) ənt (end) \\
\hline थ & $/ \mathrm{t}^{\mathrm{h}}, \mathrm{t}^{\mathrm{h}} /$ & हाथ (hāth) ha:th (hand) \\
\hline द & $/ \mathrm{d}, \mathrm{d} /$ & दो (do) do: (two) \\
\hline ध & $/ \mathrm{d}^{\mathrm{h}}, \mathrm{d}^{\mathrm{h}} /$ & दूध (dūdh) dूu:d ${ }^{\mathrm{h}}$ (milk) \\
\hline
\end{tabular}




\begin{tabular}{|c|c|c|}
\hline न & $/ \mathrm{n} /$ & नमक (namak) $\mathrm{n} \Lambda . \mathrm{m} \Lambda \mathrm{k}$ (salt) \\
\hline प & $/ \mathrm{p} /$ & पति (pati) pə.ti: (husband) \\
\hline फ & $/ \mathrm{p}^{\mathrm{h} /}$ & फल (phal) p pəl (fruit) \\
\hline ब & $/ \mathrm{b} /$ & बू (bū) bu: (odor) \\
\hline भ & $/ \mathrm{b}^{\mathrm{h} /}$ & भागना (bhāgnā) b ${ }^{\mathrm{h}} \mathrm{a}: \mathrm{g} \cdot n \mathrm{na:}$ (to run) \\
\hline म & $/ \mathrm{m} /$ & 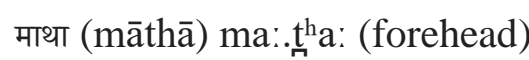 \\
\hline य & $/ \mathrm{j} /$ & योग (yog) jo:g (yoga) \\
\hline र & $/ \mathrm{r}, \mathrm{s} /$ & रोक (rok) ro:k (arrêt) \\
\hline ल & $/ 1 /$ & लाना (lānā) la:.na: (to bring) \\
\hline व & $/ \mathrm{v}, \beta, \beta, \mathrm{v}, \mathrm{w} /$ & हवा (havā) hə.va: (air) \\
\hline श & $/ 2 /$ & 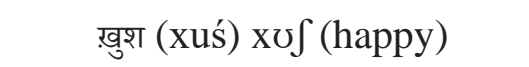 \\
\hline ष & /s, S/ & भाषा (bhāșā) b ba:.sa: (language) \\
\hline स & $/ \mathrm{s} /$ & सात (sāt) sa:t (seven) \\
\hline ह & $/ \mathrm{h}, \mathrm{h} /$ & होना (honā) fio.na: (to be) \\
\hline ज़ & $|z|$ & ज़हर (zahar) zə.hər (poison) \\
\hline झ & $|3|$ & झाला (žālā) za:.la: (hail) \\
\hline ड़ & $/ \mathfrak{r} /$ & सड़क (saṛak) sə.rək (road) \\
\hline फ़ & /f/ & फ़ैसला (faislā) fe:s.la: (decision) \\
\hline$ढ$ & $/ \mathrm{r}^{\mathrm{h}} /$ & पढ़ना (paṛhnā) pər ${ }^{\mathrm{i}} \cdot$ na: (to read) \\
\hline
\end{tabular}




\section{Appendix B}

Words and IPA Transcription

\begin{tabular}{|c|c|c|}
\hline S.No. & Word & IPA Transcription \\
\hline 1. & Lovely & /'1nvli/ \\
\hline 2. & Auspicious & 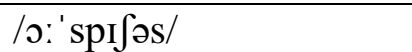 \\
\hline 3. & Honorable & /'pn(ə)rəb(ə)1/ \\
\hline 4. & Yellow & /'jeləo/ \\
\hline 5. & Hour & /'avə(I)/ \\
\hline 6. & X-ray & / 'cks, reI / \\
\hline 7. & $\begin{array}{l}\text { School, } \\
\text { Architect }\end{array}$ & $\begin{array}{l}\text { /sku:1/ } \\
\text { /'a:kıtckt/ }\end{array}$ \\
\hline 8. & Emergency & /I'mə:dz(ə)nsi/ \\
\hline 9. & Universal & /ju:nı'və:s(ə)1/ \\
\hline 10. & Unusual & 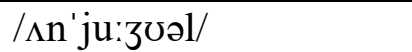 \\
\hline
\end{tabular}




\section{References}

Dhillon, R.S., et al. "Practical English Grammar." English Improvement Course, 9th ed., Dhillon Group of Publications, 2010, p. 66.

Nordquist, Richard. "What Are Vowels and Vowel Sounds in English?" ThoughtCo, 27 Jan. 2020, www.thoughtco.com/vowel-sounds-and-letters-1692601.

Sarangi, Jaydeep. "Phonetics." A Textbook of Linguistics and Phonetics, 4th ed., Books Way, 2011, p. 141. 